\title{
MODELING OF THE LINEN FABRIC DYEING AFTER PREVIOUS PREPARATION
}

Nemanja Vučković ${ }^{\star}$, Marija Kodrić, Milena Nikodijević, Dragan Đordjević

University of Niš, Faculty of Technology Leskovac, Serbia

The study deals with modeling of linen fabric dyeing after previous scouring and bleaching. The results reveal the process of the direct dye adsorption on the fabric, as well as the capacity and energy of adsorption based on which the optimization of the dyeing process with maximum performance and minimal costs can be done. With the increase of the dye concentration during dyeing, the degree of exhaustion decreases while the longer dyeing time gives a higher degree of dye exhaustion. Variation in the adsorbed amount of adsorbate increases with the increased initial concentration and time, i.e. a bigger amount of the dye or a longer time period of dyeing causes a bigger quantity of the adsorbed dye per mass unit of the linen fabric. The advantage in results processing is given to Freundlich-s model since the maximal value of the determination coefficient can be obtained.
(ORIGINAL SCIENTIFIC PAPER) UDC 677.027:677.074:677.11

Keywords: dyeing, linen fabric, direct dye, modeling, Langmuir's model, Freundlich's model.

\section{Introduction}

Because of good mechanical characteristics, thermostability, raw material renewability and biodegradability, natural fibers become more interesting for use in textile and can evenly replace artificial materials $[1,2]$.

Parameters that are decisive for using natural-cellulose fibers are [3]:

- $\quad$ Lower price compared to higher property fibers.

- $\quad$ High elasticity module and low elongation at break.

- $\quad$ They origin from natural resources.

Flax fibers have similar mechanical properties as glass fibers and some carbon fibers. Because of micro-morphological characteristics, they have smaller density, a rough surface, a specific layered structure, they are air permeable and absorptive and therefore cannot cause some allergic reactions [4].

On the other hand, various chemical modifications of cellulose fibers are possible (acetylation, cyanoethylation, treatment with alkaline) for both natural and artificial fibers. The advantage of these modifications is that fibers, especially natural ones possess the structure with good physical-mechanical properties [5].

Considering its chemical composition and morphology, flax is a very demanding substrate for the preparation process. Many fibers impurities, like lignin, pectin etc., require the preparation that is long lasting and divided in many individual processes, and they are related to high costs. Flax contains almost $20 \%$ more impurities compared to cotton [6, 7].

Demands in terms of a degree in the whiteness of flax became greater in time, and a different quality of harvest very often causes changes in the initial whiteness of flax.

A new technological approach has replaced these two bulky processes with another two important ones: cold chlorite bleaching and hot peroxide bleaching. The combination of optimizing cold chlorite bleaching with hot peroxide bleaching enables making shorter operations in a very simple and effective way [8].

The modeling of linen fabric dyeing after preparation processes, scouring and bleaching was studied in this work. The results are satisfying considering the way of direct dye adsorption on a fabric, as well as the capacity and energy of adsorption, based on what we can optimize the process of dyeing with maximum performance and minimal costs.

\section{Experimental}

In the study, $100 \%$ of raw linen fabric in plain weave was used. Basic characteristics are as follows: warp and weft count, 73 and 63 tex (unit for fineness), respectively; surface mass $238 \mathrm{~g} \cdot \mathrm{m}^{-2}$, setting of warp and weft, 17 and $16 \mathrm{~cm}^{-1}$, respectively, thickness $0.53 \mathrm{~mm}$.

Dyeing of linen fabric was performed with the direct dye Solophenyl green 5BL (Huntsman, USA).

The pretreatment of linen fabric includes processes of scouring and bleaching. Scouring of linen was carried out within 6 minutes at the temperature of $95^{\circ} \mathrm{C}$, in the ratio of the solution $1: 80$ and with the addition of sodiumcarbonate $\mathrm{Na}_{2} \mathrm{CO}_{3}$ (Tehnohemija, Serbia).

The complete bleaching was done in two steps. The first step includes a treatment in the solution with the ration $1: 100$, for 30 minutes at the temperature of $40-50{ }^{\circ} \mathrm{C}$, in the presence of $0.5 \mathrm{~g} \cdot \mathrm{dm}^{-3}$ potassiumpermanganate $\mathrm{KMnO}_{4}$ (Centrohem, Serbia), after which the abundant was rinsed with cold and hot water.

\footnotetext{
*Author address: Nemanja Vučković, Faculty of Technology,

16000 Leskovac, Bulevar oslobodjenja 124, Serbia

E-mail: vucko989@gmail.com

The manuscript received: November, 15, 2018.

Paper accepted: December, 10, 2018
} 
The second step of the sample bleaching was performed in the solution with ratio of $1: 100$. The reaction lasted for 30 minutes, at the temperature of $40-50^{\circ} \mathrm{C}$, with the addition of $3 \mathrm{~g} \cdot \mathrm{dm}^{-3}$ ascorbic acid, $\mathrm{C}_{6} \mathrm{HO}_{6}$ (Oleohemija, Serbia). At the end, the samples were abundantly rinsed with hot and cold water and sent to dry.

Dyeing was performed with a direct green dye solution (ratio $1: 50$ ) at $95{ }^{\circ} \mathrm{C}$. The concentrations of the dye Solophenyl green $5 B L$ were $10,20,40,60 \mathrm{mg} \cdot \mathrm{dm}^{-3}$. The duration time of the dyeing process was 5, 10, 20, 40 and 60 minutes.

At the end of dyeing, the fabric sample was taken out of the solution. The rest of the solution was cooled down, and the adsorption was measured on spectrophotometer (Cary 100 Conc UV-VIS, Varian), with the maximum adsorption for a direct green dye $\lambda_{\max }=680 \mathrm{~nm}$ (obtained by measurement).

A degree of dye exhaustion (\%) was calculated according to equation [9]:

Dye exhaustion $=\frac{c_{0}-c_{t}}{c_{0}} \cdot 100$

where: $C_{o}$ and $C_{t}-\left(\mathrm{mg} \cdot \mathrm{dm}^{-3}\right)$ initial and the concentration of the dye in time $t$.

The quantity of the absorbed dye per unit of the linen mass was measured with the equation [9]:

$g_{t}=\frac{c_{0}-c_{t}}{w} \cdot V$ and $g_{e}=\frac{c_{0}-c_{e}}{w} \cdot V$

where: $q_{t}-\left(\mathrm{mg} \cdot \mathrm{g}^{-1}\right)$ mass of the absorbed dye per linin mass unit at the time of dyeing $t ; q_{e}-\left(\mathrm{mg} \cdot \mathrm{g}^{-1}\right)$ mass of the absorbed dye per unit of the linen mass in balance, $C_{o}-$ $\left(\mathrm{mg} \cdot \mathrm{dm}^{-3}\right)$ the initial concentration of the dye, $C_{t}-\left(\mathrm{mg} \cdot \mathrm{g}^{-1}\right)$ the concentration of the dye in a the solution at the time of dyeing $t, C_{e}-\left(\mathrm{mg} \cdot \mathrm{dm}^{-3}\right)$ the equilibrium concentration of the dye in the solution, $w-(g)$ the sample mass of linen and $V-\left(\mathrm{dm}^{3}\right)$ the volume of the dyeing solution.

For modeling of dyeing of linen two adsorption models are used, Langmuir's and Freundlich's.

Langmuir's adsorption isotherm describes the adsorption on the homogenic surface of adsorbents that contains the limited number of identical adsorption sites and the absence of interaction between adsorbed molecules.

Langmuir's adsorption model is represented with the equation [10]:

$\frac{1}{q_{e}}=\frac{1}{Q_{0}}+\left[\frac{1}{b Q_{0}}\right] \cdot \frac{1}{C_{e}}$

where: $q_{\mathrm{e}}-\left(\mathrm{mg} \cdot \mathrm{g}^{-1}\right)$ is the quantity of adsorbed adsorbate per mass unit of adsorbent - linen, $Q_{o}-\left(\mathrm{mg} \cdot \mathrm{g}^{-1}\right)$ adsorption capacity, $b-\left(\mathrm{dm} 3 \cdot \mathrm{mg}^{-1}\right)$ adsorption energy and $C_{e}-$ $\left(\mathrm{mg} \cdot \mathrm{dm}^{-3}\right.$ ) equilibrium concentration of adsorbate - dye in the solution.

Freundlich's adsorption isotherm has the empirical character and describes the adsorption on an energetically heterogenic surface on which adsorbed molecules interact. Multilayer adsorption is well described with this model.

Freundlich's model is presented with the following equa- tion [10]:

$\ln g_{e}=\ln K_{f}+\frac{1}{n} \cdot \ln C_{e}$

where: $K_{F}-\left(\mathrm{mg} \cdot \mathrm{g}^{-1}\right) \cdot\left(\mathrm{dm}^{3} \cdot \mathrm{mg}^{-1}\right)^{(\mathrm{n}-1)}$ and $n-$ characteristic constants for the predicted system: adsorbent, adsorbate and the solution.

\section{Results and discussion}

The influence of the initial dye concentration on adsorption - exhaustion, as well as the influence on the quantity of the adsorbed dye on fiber while dyeing for different times is presented in the diagram in Figure 1. With the increase of the concentration of the dye, a degree of exhaustion is reducing depending on the time of adsorption - dyeing. At the beginning, with lower concentrations of the dye, there is a bit bigger decrease in the percentage of the dye exhaustion, but at the end, a decrease is something slighter.

The shortest time of dyeing ( 5 minutes) causes the smallest exhaustion degree values, while the longest dyeing time (60 minutes) generates the highest values of the exhaustion degree.

With the increase of the initial concentration of the dye, the adsorption of the dye per mass unit of linin fiber grows rapidly, continuously during time.

Figure 2 shows the impact of time or the length of the contact between adsorbate (dye) and adsorbent (linen fabric) on adsorption - exhaustion of the dye during dyeing on different initial concentrations of a direct dye. At the beginning, with every initial concentration there is a rapid growth of dye exhaustion, and after about 10 minutes of dyeing, this trend is weaker until the end of dyeing.

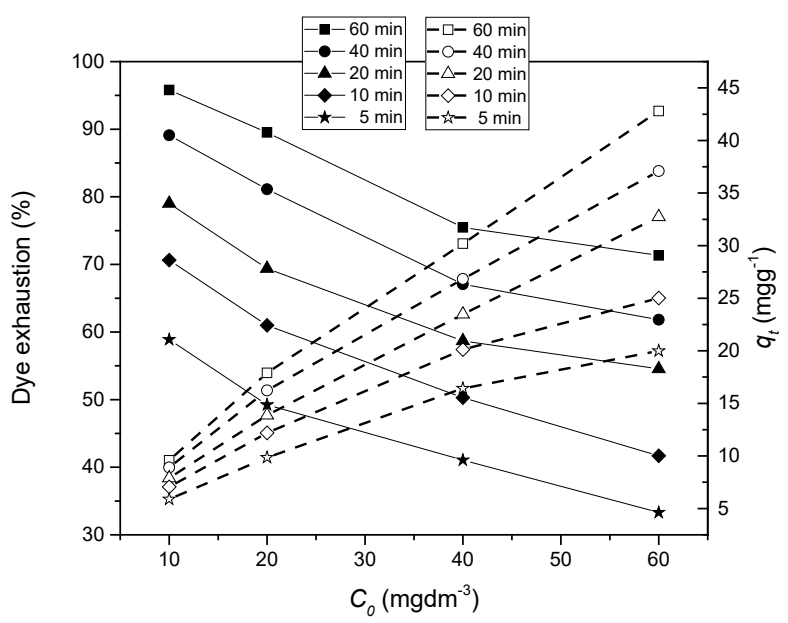

Figure 1. The impact of the initial concentration of the dye on the exhaustion degree and the quantity of the adsorbed dye on the flax fiber during dyeing (Dye exhaustion - black symbols, full line; $q_{t}-$ white symbols, interrupted line) 


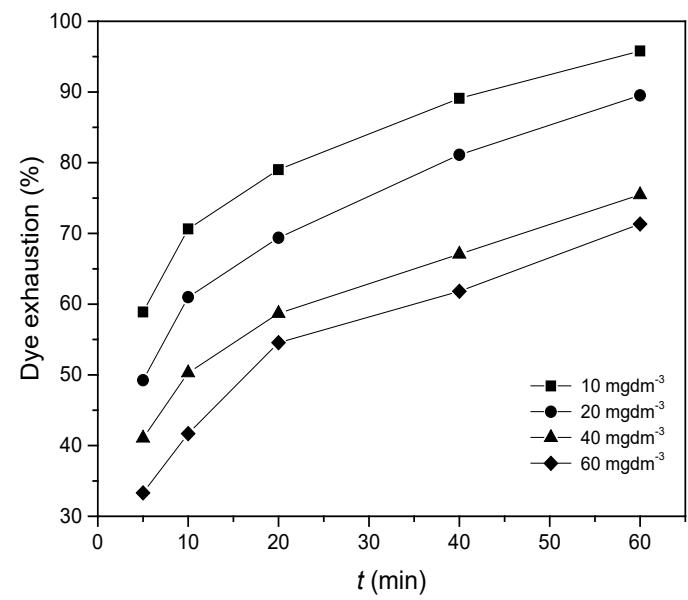

Figure 2. The impact of time on the exhaustion degree of direct green dye during the dyeing of the flax fiber

Figure 3 presents the changes in the concentration and quantity of the adsorbed dye on linen fabric during dyeing for different initial concentrations. A relatively slight change in the concentration of the dye as the dyeing time increases can be noticed. The change is intense at the beginning and, after 20 minutes, it is quite slower. Over time, at higher dye concentrations, a slightly steeper drop of curves at the beginning of coloring occurs, which is associated with the rapid bonding of the dye on the fabric, given a big difference in the gradient of the concentration.

The start of dyeing brings about quicker dyeing in the first 20 minutes, i.e. a larger amount of the adsorbed dye appears per unit mass of the adsorbent, so that later, with the prolongation of the dyeing time this binding is somewhat slower. At the highest applied initial dye concentrations and the longest dyeing, the highest adsorption occurs.

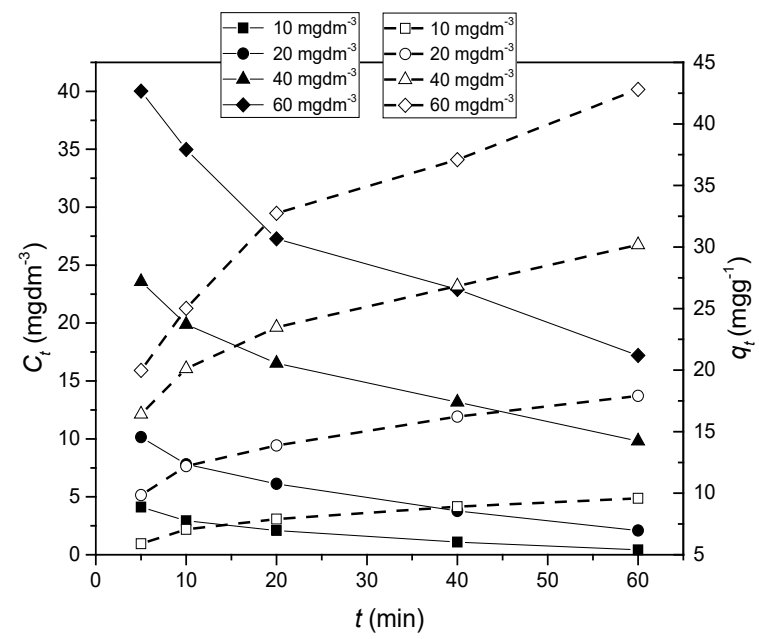

Figure 3. The change of the concentration and quantity of the adsorbed dye on the linen fabric during dyeing for different initial concentrations $\left(C_{t}-\right.$ black symbols, full line; $q_{t}$ - white symbols, interrupted line)
Figure 4 shows the appearance of the linen fabric in individual finishing phases and after dyeing. There is a significant difference according to the processing types: scouring, bleaching and dyeing.

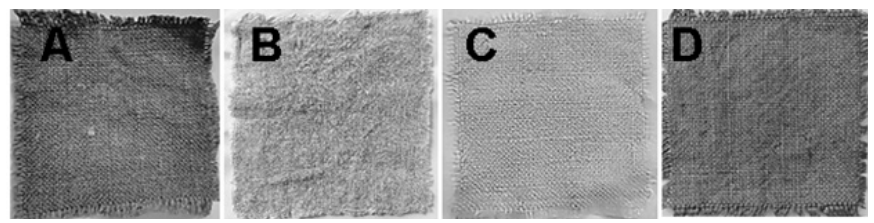

Figure 4. Raw (A), scoured (B), bleached (C) and dyed (D) samples of linen fabric

A similar study focused on the colors of different pretreated flax fibers (alkaline, acidic and enzymatic), dyed both conventionally and ultrasonically using two red direct dyes with different molecular mass, in terms of the exhaustion rate etc. Dyeing was accomplished according to both a conventional dyeing procedure (without the ultrasound power) and an ultrasonic technique, using two direct dyestuffs: $\mathrm{Cl}$ Direct Red 80 (dye 1) and $\mathrm{Cl}$ Direct Red 81 (dye 2) [6].

Exhaustion curves define the time dependent distribution of the dye between the dyebath and flax fibers throughout the dyeing process and indicate the dye adsorption at the surface of the fiber and diffusion into the fiber as a function of time. The obtained results demonstrate that different pretreatments of flax could influence the dyeing behavior depending on the time and, above all, the type of the dyeing procedure. During conventional dyeing, the dyeing rate slightly increased in the first stage of the process (the first $30 \mathrm{~min}$ ), most likely on account of very strong repulsion forces between the large dye molecule and the fiber [6].

After raising the temperature of the dyebath up to 98 ${ }^{\circ} \mathrm{C}$ (after $50 \mathrm{~min}$ ), the exhaustion rapidly increased, especially for enzymatic and acidic pretreated samples, implying a shorter time required to reach the state of equilibrium. Later (after $78 \mathrm{~min}$ ), the differences in the curve between different scoured samples were minor. The final exhausted dye 1 after 92 min of dyeing was $94 \%$ for acidic and enzymatically pretreated fibers, followed by $95 \%$ for alkali-scoured fibers. Generally, final amounts of dyestuff exhausted over ultrasound assistance were higher, and the time attaining equilibrium was shorter [6].

Dyeing with dye 2 is based on dissimilar exhaustion behavior than when using dye 1. Because of the smaller dye molecule, and hence better diffusion, the exhaustion curves show greater slopes during the first division of the dyeing process than on the earlier graphs, although stronger migration of the dye is presented. During the ultrasonic-assisted dyeing of different pretreated samples, the degradation of dye 2 was observed after $60 \mathrm{~min}$ after the processes had started, which is not evident [6].

A diagram (Figure 5) represents Langmuir's adsorption isotherms for dyeing of linen fabric at the temperature of $95{ }^{\circ} \mathrm{C}$, showing the dependency of parameters $\left(1 / q_{e}\right)$ in relation to the equilibrium concentration of the 
dye $\left(1 / C_{e}\right)$.

From the slopes and intercept of linear fit, the values of Langmuir's constants are determined, $Q_{0}=33.3 \mathrm{mg} \cdot \mathrm{g}^{-1}$ and $b=0.94 \mathrm{dm}^{3} \cdot \mathrm{mg}^{-1}$. They are related to the maximum quantity of adsorbate that can be bounded on adsorbent and the free adsorption energy, respectively. The analytical expression of Langmuir's isotherm is $\frac{1}{q}=0,030$ $+0,032 \frac{1}{c}$, while the coefficient of the determination is $R^{2}=0.95$. ${ }^{e}$ The model is more representable when the coefficient of determination is closer to one.

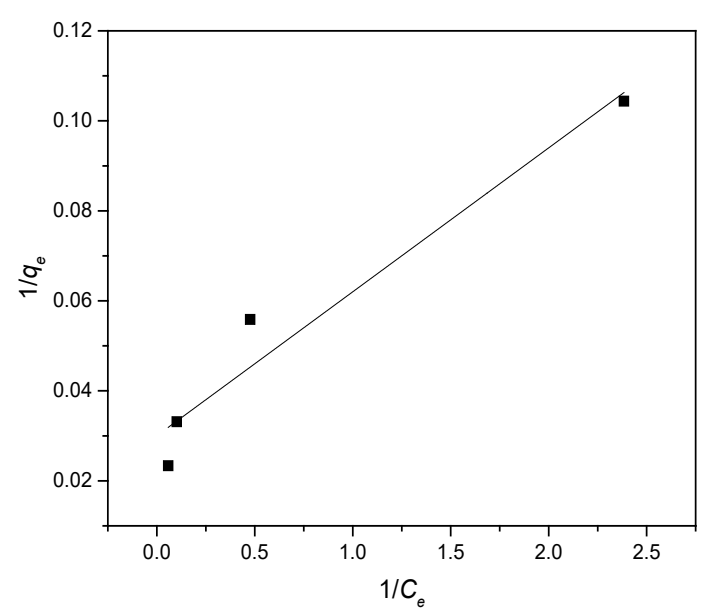

Figure 5. Langmuir's linear regression model for balanced dyeing of the linen fabric

Langmuir's isotherm can also be expressed with nondimensional constant, parameter of equilibrium $R_{L}$. The value of $R_{L}$ predicts if the isotherm is unfavorable $\left(R_{L}>1\right)$, linear $\left(R_{L}=1\right)$, favorable $\left(0<R_{L}>1\right)$ or irreversible $\left(R_{L}=0\right)$. From the value of $\mathrm{b}$ and the biggest initial quantity of green dye $\left(60 \mathrm{mg} \cdot \mathrm{dm}^{-3}\right), R_{L}$ is determined to be 0.15 . These results confirm that the Langmuir's model is convenient for description adsorption - dyeing in the case.

The diagram in Figure 6 represents Freundlich's isotherm for the adsorption of the dye on adsorbent for the constant quantity of the linen fabric and the temperature of $95{ }^{\circ} \mathrm{C}$. From this diagram, very high functionality of variables is noticeable, higher than registered at Langmuir's model. Based on this diagram, Freundlich's constants are determined.

$K_{F}$, one of the Freundlich's constants, is used as a relative measure of the adsorption capacity. A bigger value $\left(K_{F}=13.3\right.$ in concrete case $)$ indicates a bigger adsorption capacity.

The second Freundlich's constant, $n$, is an empirical parameter that changes with the degree of heterogenic indication, the degree of non-linearity between the capacity of the adsorbed dye and the concentration of non-adsorbed dye. Generally, $1 / n<1$ shows that the adsorbate is sufficiently adsorbed on the adsorbent, the adsorption capacity rises, new positions appear for adsorption, the value of $n$ is greater, the intensity of the adsorption is stronger. The results confirm that $n>1$, i.e. $2.6>1$, or, $1 / 2.6<1$, i.e. $0.38<1$. The analytical expression of Freundlich's model is $\ln q_{e}=2,59+0,39 \cdot \ln C_{e}$.

A coefficient of determination of Freundlich's isotherm is bigger than the one of Langmuir's expression, reaching the value very close to $1(0.99)$, which represents the excellent, almost absolute functionality. This means that both models can be used to describe the adsorption of a direct green dye on adsorbent but the advantage is given to the Freundlich's model because of the bigger maximum value $R^{2}$.

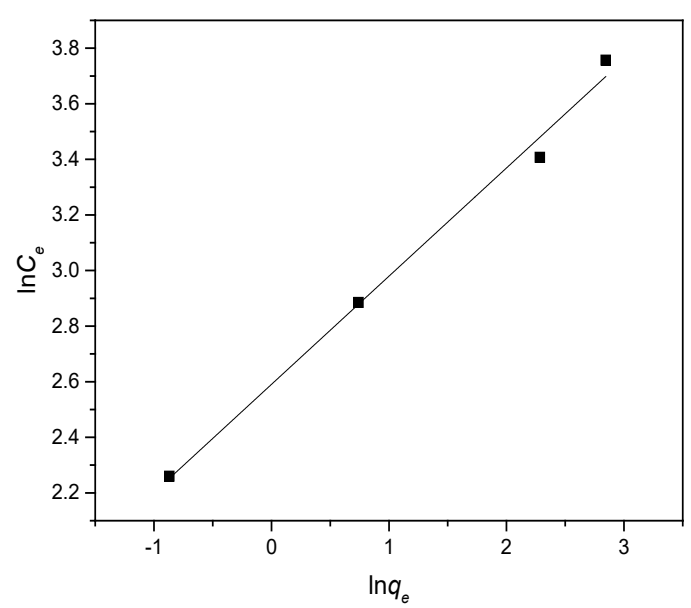

Figure 6. Freundlich's linear regression model for balanced dyeing of the linen fabric

\section{Conclusion}

With modeling the dyeing process, the data that connect the dye concentration, the temperature, the presence of electrolytes and the efficiency of achieved dyeing on the fabric, i.e. the quantity of the waste dye that is left after dyeing were obtained.

Based on the obtained experimental results it can be concluded:

- Dyeing of the linen fabric with a direct dye in laboratory conditions gives excellent results at the temperature of $95^{\circ} \mathrm{C}$.

- With the increase of the dye concentration while dyeing, the degree of exhaustion reduces.

- The longer time of dyeing gives a higher degree of dye exhaustion.

- The change of the adsorbed quantity of adsorbate on adsorbent increases with the increase of the initial quantity and time, i.e. a bigger quantity of the dye or longer time of dyeing give a larger quantity of the adsorbed dye per mass unit of the flax fiber.

- Both models can be used to describe direct dye adsorption on the linen fabric, but the advantage is given to Freundlich's model due to the maximum value of the coefficient of determination.

References 


\section{References}

[1] I. Booth, R. J. Harwood, J.L. Wyatt, S. Grishanov, A comparative study of the characteristics of fibreflax (Linum usitatissimum), Industrial Crops and Products, 20 (2004) 89-95.

[2] S. Michel, R. Vogels, N. Bouvy, M. Knetsch, N. van den Akker, M. Gijbels, C.van der Marel, J. Vermeersch, D. Molin, L. Koole, Utilization of flax fibers for biomedical applications, Journal of biomedical materials research b: applied biomaterials, 102b (2014) 477-487.

[3] J. Garcia-Ubasart, A.L. Torres, C. Vila, F.I. JavierPastor, T. Vidal, Biomodification of cellulose flax fibers by a new cellulase, Industrial Crops and Products, 44 (2013) 71-76.

[4] L. Boulos, M. Foruzanmehr, A. Tagnit-Hamou, S. Elkouna, M. Robert, Wetting analysis and surface characterization of flax fibers modified with zirconia by sol-gel method, Surface \& Coatings Technology 313 (2017) 407-416.

[5] A.K. Mohanty, M.A. Khan, G. Hinrichsen, Surface modification of jute and its influence on performance of biodegradable jute-fabric/Biopol composites, Composites Science and Technology 60 (2000) 1115-1124.
[6] D. Fakin, A. Ojstrsek, Colour of flax fibres in regard to different pretreatment and dyeing processes, Society of Dyers and Colourists, 124 (2008) 216222.

[7] D. Fakin, V. Golob, K. Stana-Kleinschek, A. Majcen Le Marechal, Sorption Properties of Flax Fibers Depending on Pretreatment Processes and their Environmental Impact, Textile Research Journal, 76 (2006) 448-454.

[8] A. Bernava, S. Reihmane, Influence of modification methods on colour properties of a linen fabric dyed with direct dyes, Proceedings of the Estonian Academy of Sciences, 67 (2018) 131-137.

[9] S.S. Abkenar, R.M. Malek, F. Mazaheri, Dye adsorption of cotton fabric grafted with PPI dendrimers: Isotherm and kinetic studies, Journal of Environmental Management, 163 (2015) 53-61.

[10]F. Carrillo, M.J. Lis, J. Valldeperas-Morell, Sorption isotherms and behaviour of direct dyes on lyocell fibres, Dyes and Pigments, 53 (2002) 129-136.

\section{Izvod \\ MODELOVANJE BOJENJA LANENE TKANINE POSLE PRETHODNE PRIPREME}

Nemanja Vučković, Marija Kodrić, Milena Nikodijević, Dragan Đorđević

Univerzitet u Nišu, Tehnološki fakultet u Leskovcu, Srbija

Rad se bavi modelovanjem bojenja lanene tkanine posle iskuvavanja i beljenja. Rezultati su zadovoljavajući s obzirom da otkrivaju način adsorpcije direktne boje za vlakno kao i kapacitet i energiju adsorpcije, na osnovu čega se može optimizovati proces bojenja uz maksimalni učinak i minimalne troškove. Porastom koncentracije boje pri bojenju smanjuje se stepen iscrpljenja dok duže vreme bojenje daje i veći stepen iscrpljenja boje. Promena adsorbovane količine adsorbata na adsorbentu, raste tokom povećanja početne koncentracije i vremena, tj. veća količina boje ili duži vremenski period bojenja donose veću količinu adsorbovane boje po jedini mase lanene tkanine.Oba modela, Freundlich i Langmuir, mogu se upotrebiti za opis adsorpcije direktne boje na adsorbent, s tim da se prednost daje Freundlich-ovom modelu zbog maksimalne vrednosti koeficijenta determinacije.
(ORIGINALNI NAUČNI RAD) UDK 677.027:677.074:677.11

Ključne reči: bojenje, lanena tkanina, direktna boja, modelovanje, Langmuir-ov model, Freundlich-ov model. 